\title{
Testicular Diffuse Large B-Cell Lymphoma
}

National Cancer Institute

\section{Source}

National Cancer Institute. Testicular Diffuse Large B-Cell Lymphoma. NCI Thesaurus.

Code C162467.

A diffuse large B-cell lymphoma that arises from the testis. It predominantly affects older men. Patients usually present with a unilateral hard painless mass. Bilateral masses have been described in a minority of patients. 